INFORMAATIOTUTKIMUKSEN PÄIVÄT 2020

\title{
Disnormatiivinen informaatio Tor-verkossa
}

\author{
Ari Haasio \\ Seinäjoen ammattikorkeakoulu \\ ari.haasio@seamk.fi \\ https://orcid.org/0000-0003-3723-4890 \\ J. Tuomas Harviainen \\ Tampereen yliopisto \\ tuomas.harviainen@tuni.fi \\ https: //orcid.org/0000-0002-6085-5663
}

Asiasanat: Tor-verkko, disnormatiivinen informaatio, verkkorikollisuus, pimeä netti, informaatio

Pimeä verkko eli Dark Web (Gehl 2018) on anonyymin informaation liikkumisen mahdollistava, erillisellä selaimella käytettävä verkko. Siitä käytetään usein myös nimeä Tor-verkko, koska palvelua voidaan käyttää esimerkiksi Tor-selaimen avulla. Anonyymin luonteensa vuoksi se soveltuu hyvin esimerkiksi rikolliseen toimintaan (vrt. esim. Haasio, Harviainen \& Savolainen 2020).

Disnormatiivinen informaatio voidaan Haasion (2015; 2019) mukaan määritellä informaatioksi, joka on luonteeltaan yhteiskunnan enemmistön arvojen, asenteiden tai vaihtoehtoisesti myös lainsäädännön vastaista. Tämän Artikkeli on lisensoitu Creative Commons Nimeä-EiKaupallinen-JaaSamoin 4.o Kansainvälinen -lisenssillä Pysyvä osoite: https://doi.org/10.23978/inf. 98594 
tyyppistä informaatiota on esimerkiksi huumeiden käyttöön ja myyntiin liittyvä informaatio, kuten Haasio, Harviainen ja Savolainen (2020) ovat todenneet tutkiessaan Tor-verkon huumekauppaan ja -kulttuuriin keskittyneen Sipulitorin keskusteluissa esiintyneitä tiedontarpeita.

Burnett ja Lloyd (2020) ovat lanseeranneet käsitteen Dark Knowledge, joka on läheistä sukua disnormatiiviselle informaatiolle. Pimeässä tiedossa painottuvat ennen muuta tiedon kielletty luonne esimerkiksi uskonnollisista tai moraalisista syistä, sekä tiedon vaarallisuus, joka voi liittyä esimerkiksi tuhoisaan tai ei-toivottuun käytökseen. Yksi keskeisistä käsite-eroavaisuuksista on siinä, puhutaanko informaatiosta vai tiedosta. Tässä emme paneudu tarkemmin näiden käsitteiden välisiin eroihin ja yhtäläisyyksiin vaan keskitymme siihen, millaista disnormatiiviseksi informaatioksi tai pimeäksi tiedoksi luokiteltavaa aineistoa Tor-verkossa liikkuu.

Kuten Burnett ja Lloyd (2020) ovat huomauttaneet, kaikki pimeä tieto ei ole luonteeltaan vahingollista henkilöille tai organisaatiolle. Sen sijaan käsitteellä voidaan viitata myös sellaiseen informaatioon, joka on tietoisesti piilotettu, ettei se tulisi julkiseksi tai ettei sitä havaittaisi. Kyse voi olla esimerkiksi moraalisesti arveluttavasta, mutta sinänsä laillisesta informaatiosta, jota ei haluta julkiseen levitykseen sen arkaluontoisuuden takia.

Huumekauppa on keskeisimpiä Tor-verkon laittomia sisältöjä. Osa palveluista on globaaleja, mutta yhä useammat verkon huumekaupat ovat erikoistuneet tarjoamaan palveluja paikallisesti tietyissä maissa. (Demant ym. 2018.) Kryptomarketeissa välitettävä informaatio on lähinnä tuotetietoa, kuvalautatyyppisissä palveluissa taas keskustellaan laajemmin huumekulttuurista ja tarjotaan myös muita laittomia palveluita (Harviainen, Haasio \& Hämäläinen 2020). Terrorismi ja ääriliikkeiden toiminta on huumekaupan lisäksi toinen Tor-verkon anonymiteettiä hyödyntävä rikollisuuden osa-alue (Chen ym. 2008; Weimann 2016). Myös laittoman pornografian ja seksuaalista väkivaltaa sisältävien materiaalien levittäminen tapahtuu usein Tor-verkon kautta (O’Brien 2014).

Pimeän verkon lainvastaiseen toimintaan keskittyneitä sivustoja voidaan ajatella olevan eräänlaisia illegaaleja "virtuaalisia pieniä maailmoja" (vrt. Burnett, Besant \& Chatman 2001; Burnett \& Buerkle 2004), joissa välitetään lainvastaista ja moraalitonta informaatiota ja tyydytetään niihin liittyviä tiedontarpeita.

Aihepiirin empiirinen tutkimus on hyvin vähäistä. Burnettin ja Lloydin (2020) artikkeli on puhtaasti käsitteellinen analyysi. Disnormatiivista informaatiota on käsitelty muutamassa julkaisussa myös empirian tasolla (Haasio 2015; Haasio, Harviainen \& Savolainen 2020). Aihe vaatiikin tarkempaa empiriaan perustuvaa tutkimusta informaatiokäyttäytymisen eri näkökulmista 
näiden käsitteiden selkiyttämiseksi. On kuitenkin syytä muistaa, että disnormatiivista informaatiota ei liiku pelkästään Tor-verkossa. Esimerkiksi tämän tyyppistä huumeisiin liittyvää informaatiota välitetään myös sosiaalisen median eri palveluissa (esim. Demant ym. 2019; Moyle ym. 2019; Oksanen ym. 2020), mikä tulee myös huomioida jatkotutkimuksessa.

\section{Lähteet}

Burnett, G., Besant, M., \& Chatman, E. A. (2001). Small worlds: Normative behavior in virtual communities and feminist bookselling. Journal of the Association for Information Science and Technology, 52(7), 536-547. https://doi.org/10.1002/asi.1102

Burnett, G., \& Buerkle, H. (2004). Information exchange in virtual communities: A comparative study. Journal of Computer-Mediated Communication, 9(2), JCMC922. https://doi. org/10.1111/j.1083-6101.2004.tb00286.x

Burnett, S., \& Lloyd, A. (2020). Hidden and forbidden: conceptualising Dark Knowledge. Journal of Documentation 76(6), 1341-1358. https://doi.org/10.1108/JD-12-2019-0234

Chen, H., Chung, W., Qin, J., Reid, E., Sageman, M., \& Weimann, G. (2008). Uncovering the dark web: a case study of Jihad on the web. Journal of the American Society for Information Science and Technology, 59(8), 1347-1359. https://doi.org/10.1002/asi.20838

Demant, J., Bakken, S. A., Oksanen, A., \& Gunnlaugsson, H. (2019). Drug dealing on Facebook, Snapchat and Instagram: A qualitative analysis of novel drug markets in the Nordic countries. Drug and alcohol review, 38(4), 377-385. https://doi.org/10.1111/dar.12932

Demant, J., Munksgaard, R., Décary-Hétu, D., \& Aldridge, J. (2018). Going local on a global platform: A critical analysis of the transformative potential of cryptomarkets for organized illicit drug crime. International Criminal Justice Review, 28(3), 255-274. https://doi. org/10.1177\%2F1057567718769719

Gehl, R. W. (2018). Weaving the Dark Web: Legitimacy on Freenet, Tor, and I2P. Cambridge, MA.: MIT Press. https://doi.org/10.7551/mitpress/11266.001.0001

Haasio, A. (2015). Toiseus, tiedontarpeet ja tiedon jakaminen tietoverkon "pienessä maailmassa": tutkimus sosiaalisesti vetäytyneiden henkilöiden informaatiokäyttäytymisestä. Tampere, Finland: Tampere University Press (Acta Universitatis Tamperensis; 2082). http:// urn. fi/URN : ISBN : 978-951-44-9878-7

Haasio, A. (2019). What is Disnormative Information? Information and Communication Sciences Research, 23(1), 9-16. Noudettu osoitteesta https://www.ceeol.com/search/articledetail ?id=835830

Haasio, A., Harviainen, J. T., \& Savolainen, R. (2020). Information needs of drug users on a local dark Web marketplace. Information Processing \& Management, 57(2), 102080. https:// doi.org/10.1016/j.ipm. 2019.102080

Harviainen, J. T., Haasio, A., \& Hämäläinen, L. (2020, January). Drug traders on a local dark web marketplace. In Proceedings of the 23rd International Conference on Academic Mindtrek (pp. 20-26). https://doi.org/10.1145/3377290.3377293 
Moyle, L., Childs, A., Coomber, R., \& Barratt, M. J. (2019). \#Drugsforsale: An exploration of the use of social media and encrypted messaging apps to supply and access drugs. International Journal of Drug Policy, 63, 101-110. https://doi.org/10.1016/j.drugpo.2018.08.005

O'Brien, M. (2014). The Internet, child pornography and cloud computing: the dark side of the web?. Information \& Communications Technology Law, 23(3), 238-255. https://doi.org/ $10.1080 / 13600834.2014 .970376$

Oksanen, A., Miller, B. L., Savolainen, I., Sirola, A., Demant, J., Kaakinen, M., \& Zych, I. (2020, July). Illicit Drug Purchases via Social Media Among American Young People. In International Conference on Human-Computer Interaction (pp. 278-288). Cham: Springer. https:// doi.org/10.1007/978-3-030-49570-1_19

Weimann, G. (2016). Going dark: Terrorism on the dark web. Studies in Conflict \& Terrorism, 39(3), 195-206. https://doi.org/10.1080/1057610x.2015.1119546 